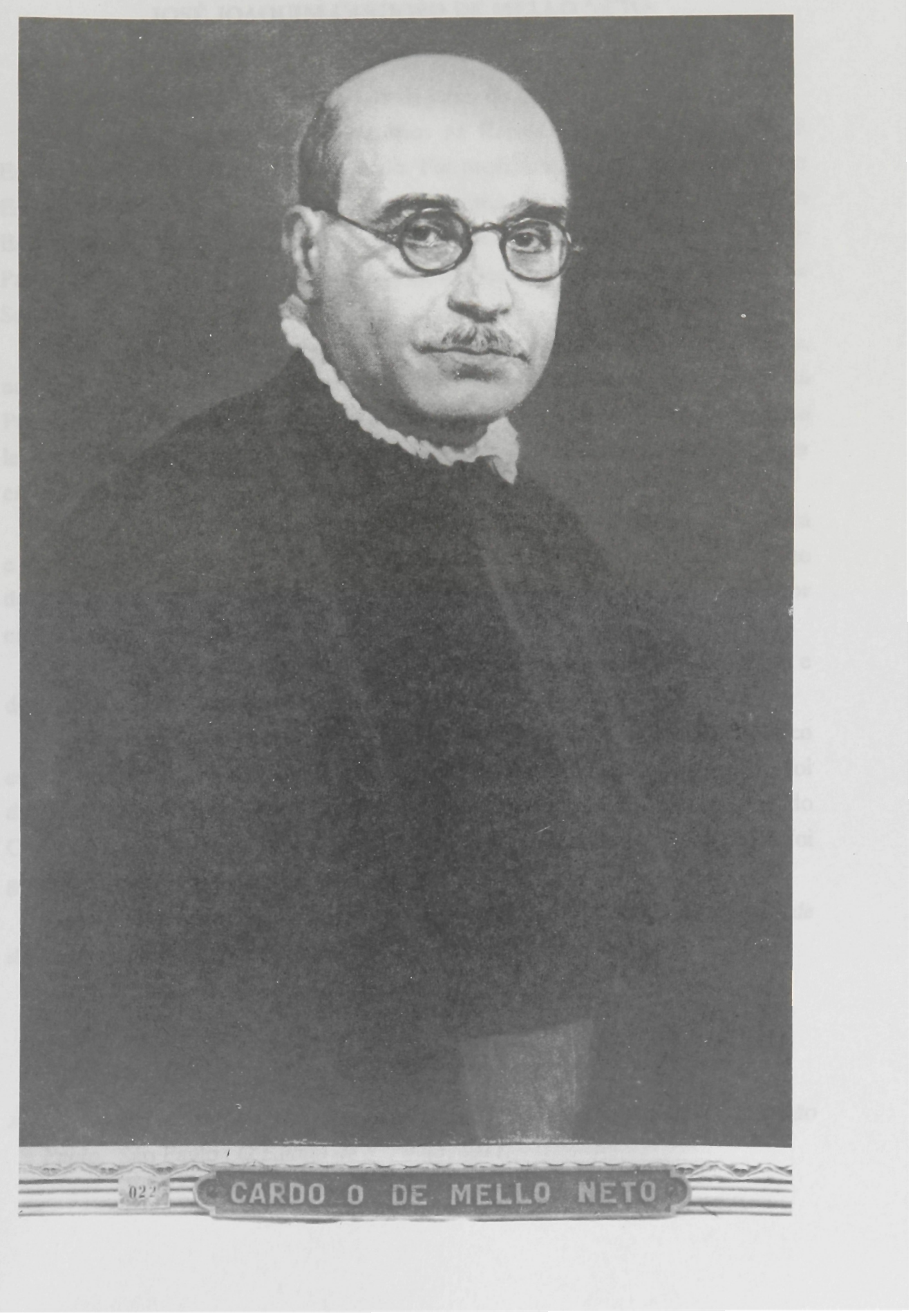





\title{
JOSÉ JOAQUIM CARDOSO DE MELLO NETO
}

\author{
(1941-1942)
}

Nasceu em São Paulo a 19 de julho de 1883.

Fez os estudos preparatórios na Escola Complementar, anexa à Escola Normal da Capital de São Paulo. Foi professor, aos 16 anos, do Grupo Escolar da Bela Vista. Fez, pouco depois, exame de madureza no Ginásio de Estado da capital, matriculando-se em 1901 na Faculdade de Direito de São Paulo. Em agosto de 1906, recebeu o grau de bacharel em Ciências Jurídicas e Sociais.

Em 1917, fez concurso para professor substituto da quinta seção, nas cadeiras de Direito Administrativo e Ciência da Administração e Economia Política e Ciência das Finanças. Classificado em primeiro lugar, foi nomeado lente substituto em outubro do mesmo ano, recebendo também o grau de doutor em Direito.

Em 1920, foi nomeado professor catedrático de Economia Política e Ciência das Finanças. Em 1941, foi nomeado diretor da Faculdade de Direito de São Paulo e em novembro de 1953 foi-lhe conferido o título de professor emérito da mesma Faculdade.

Advogado militante, foi um dos fundadores da Liga Nacionalista e do Instituto da Ordem dos Advogados de São Paulo.

No campo político, foi membro fundador do Partido Democrático em 1926; ocupou em 1930 o cargo de prefeito da capital de São Paulo e foi deputado constituinte em 1934. Em 1936, liderou a bancada do Partido Constitucionalista (oriundo do Partido Democrático) na Câmara Federal e foi governador do Estado de São Paulo em 1937.

Foi autor de inúmeros pareceres e artigos na Revista da Faculdade de Direito e na Revista dos Tribunais.

Faleceu a 20 de julho de 1965.

\section{Obras Publicadas}

A acção social do Estado: dissertação apresentada à Faculdade de Direito de São Paulo. São Paulo : O Estado de S. Paulo, 1917. 
Discriminação de rendas entre a União e os Estados: dissertação apresentada à Faculdade de Direito de São Paulo. São Paulo : O Estado de S. Paulo, 1917.

Mensagem apresentada à Assembléa Legislativa de São Paulo a 9 de julho de 1937. São Paulo : Revista dos Tribunais, 1937.

Discursos. São Paulo: Saraiva, 1938. 